\title{
THE EFFECTS OF AGENCY REFORM IN EUROPE: A REVIEW OF THE EVIDENCE
}

\author{
Pre-print version \\ Forthcoming in Public Policy and Administration
}

\author{
Sorin Dan \\ Doctoral researcher \\ KU Leuven Public Management Institute \\ Parkstraat 45, Bus 3609 \\ B-3000, Leuven, Belgium \\ E-mail: sorin.dan@soc.kuleuven.be
}

Tel: 003216323633

\begin{abstract}
This paper reviews the New Public Management (NPM) literature on the effects of the creation and ongoing operations of agencies across European public sectors. It finds that the bulk of evidence concerns internal effects on processes/activities of agency creation and management and little evidence on outputs and outcomes. The article identifies a number of patterns across the sample reviewed and finds positive effects on improved processes, and an orientation towards results and service users' needs. Similarly, it finds improvements in transparency and accountability across various countries, but evidence in these areas is less clear. It finds that $46 \%$ of the studies included in the sample identified concerns about fragmentation, coordination or organizational stability and shows that unintended consequences are an important part of the evaluation of the effects of agencification. The paper argues that the picture of the effects of agencies is nuanced and discusses possible factors that can tip the balance for or against the success of the agency model.
\end{abstract}

Keywords: Public sector agencies, effects, evidence, Europe 


\section{Introduction}

The creation of agencies has been at the core of the New Public Management (NPM). Much has been written on and commented about the suitability, advantages and problems of hiving off public tasks. It might therefore be expected that the effects of the creation and ongoing operations of agencies are well understood. However, whether agencification 'works', and the circumstances under which it does, are still unfinished tasks (Manning and Matsuda, 2000; Verhoest et al., 2012). This article reviews the NPM literature on agencies across European public sectors to identify possible patterns in the success or failure of the agency model. It does so by analysing 'internal' effects on the processes or activities of agencies as well as effects on outputs and outcomes.

To ask what the effects of agencification have been may seem like a straightforward question, but actually it is anything but. There are two principal groups of reasons why it is hard to answer: the first have to do with meaning and the second with evidence. The terms 'agency' and 'effects' have both been used with a range of meanings, so we have to be careful to specify what it is we are talking about at any particular point.

On the question of meanings, we may note that it has long been recognised that there is no standardized international view of what is an 'agency' (Pollitt et al., 2004; Pollitt and Talbot, 2004; Verhoest et al., 2012, pp. 18-21). There is no widely shared legal or constitutional category that ensures that (say) the British, the Dutch, the French and the Germans are all talking about the same thing. Neither is the cultural and political meaning of agencification similar in all countries or periods. For example, a detailed study of key official documents on agencification in Australia, the Netherlands and Sweden came to the conclusion that debates about why agencification was necessary and what it meant were quite different in each case (Smullen, 2010). Or again, during the 1990s in the UK, agencification was widely seen as giving blocks of operational activity more autonomy from ministries, while in the Netherlands one current of thought was that agencification was attractive because it placed such activities under closer ministerial supervision than would putting them into the then popular ZBO format (Van Thiel and Pollitt, 2007). A study of agencies operating in the same sectors in Finland, the Netherlands, Sweden and the UK showed that even where agencies had similar performance indicator systems, the status of these systems and the ways in which they were used varied considerably (Pollitt et al., 2004). This means that international lesson 
drawing is difficult, because similar-looking organizational structures or performance management systems may actually be operated in different ways.

\section{Theoretical background}

Scholars have repeatedly stressed that there was not one single coherent theory that fed into the NPM (Kettl, 1997). Nevertheless, economic theories, typically neo-classical and rational choice, are often considered to form the core of the theoretical basis of NPM. This includes public choice theory (Downs, 1967; Niskanen, 1968; 1971; see also Boyne et al., 2003 for an application to public services in the UK), principal-agent theory (Jensen and Meckling, 1976; see also Buchanan, 1988; Verhoest, 2005), managerialism (Pollitt, 1993) or property rights theory (for example Preker and Harding, 2003). This has been contrasted with general management theory which tends to take a more heroic view of managers - as leaders who can 'transform' their organizations, and who can change the organizational culture. So for this reason more autonomy - freedom for managers to manage - is seen as a good idea. Rational choice has very little to do with/say about cultural change, leadership and all the things which concern generic management theory. It takes a more narrowly self-interested view of motivation. The key expectation of these theories is that autonomous organizations are uniquely positioned to deliver performance - if only they were equipped with the proper incentives. The proponents of agencification were sometimes quite vague about exactly what agencification was supposed to achieve (for example Van Thiel, 2001). On other occasions, however, a variety of positive claims were made. It was assumed that executive agencies need to enjoy a certain degree of discretion so that decisions can be made on the basis of specialized expertise and customer preferences. Therefore allocative efficiency was presumed to improve following specialization and disaggregation of monolithic entities. Technical efficiency of operations was likewise believed to go up. A flexible service delivery organization is expected to be in a better position to innovate constantly and find costeffective and creative solutions to improve quality, address financial problems and adapt to changing patterns of demand. As a result public accountability and user/customer satisfaction are expected to get better. If management is empowered with the adequate decision-making capacity, it can motivate personnel by designing tailored incentives, which in turn are expected to lead to performance improvements. An expanded choice of services and maintained equity are two additional expected benefits. The overall expectation was that performance of executive agencies would improve without a significant decrease in equity or access to services. These have been the main expectations of the creation of agencies. Other 
issues such as fragmentation, coordination and their implications for systemic performance and policy coherence were not part of the original model. Weight was placed mainly on the performance of operations at unit level measured by the production of outputs (Schick, 1996).

In this article we adopt what has become a fairly standard definition of an agency (Van Thiel, 2012, pp. 18-20). The definition employed in this paper treats an agency as a public sector organization which is:

1. Structurally disaggregated from government ministries

2. Operates under more businesslike conditions than the core government bureaucracy

Such organizations operate at arms' length from the core of government and undertake public tasks such as service delivery, regulation and policy implementation.

This article distinguishes between three types of effects:

1. Activities/processes (for example budgeting, making accountability statements; organising to produce services; training staff)

2. Outputs (for example treatments/lessons/inspection/information delivered to service users; grants and loans issued)

3. Outcomes (for example improved health status for citizens; better economic growth; educational attainments for students; increased citizen satisfaction with the quality of services)

An organization or programme is conceived as a set of activities or processes. These include organizational arrangements like the division of responsibility, the allocation of authority, the standard operating procedures, and so on. These procedures enable the organization to deploy and redeploy its resources (staff, money, buildings and so forth) which are collectively termed inputs. From these activities and processes the organization or programme then produces a set of outputs, which could, for example be lessons (in a school), licenses (from a licensing agency), medical treatments (from a hospital) and so on. These outputs are, in a sense, what the organization 'gives' to the outside world - to citizens, to civil society associations and to business firms. They are like messages, passing across the membrane that separates (on the one hand) the state from (on the other) the market sector and civil society. Outputs are invariably intended to produce desirable outcomes, beyond the organization or programme - so school lessons are supposed to produce educated students and hospitalprovided medical treatments are supposed to produce the cure or the alleviation of ill-health. 
An outcome is something that happens in the world outside the organization and the programme: it is an effect 'out there in the real world'.

The performance of organizations and programmes (the value of their activities) is usually thought of in terms of certain relationships between these inputs, outputs and outcomes. Thus the ratio between inputs and outputs is a measure of efficiency (or technical efficiency or Xefficiency, or productivity). If you can get more outputs for the same inputs, you have achieved an efficiency gain. If you can maintain steady outputs while reducing inputs you have also achieved an efficiency gain - in both cases the ratio between inputs and outputs improves. Effectiveness, however, is a different concept, which is usually conceived as the degree to which the outcomes match the original goals or objectives set for the organization of programme. As many writers have remarked, if goals are multiple, conflicting or ambiguous then it will be difficult to determine effectiveness, which will, in effect, become a 'contested concept'. Unfortunately, policy goals frequently are multiple, conflicting or ambiguous, not least because that is what politicians may need to get sufficient agreement to launch the policy in the first place. This certainly includes public management reforms which are often claimed to be all things to all men - to save money, raise service quality, increase effectiveness, and so forth.

Another point to be borne in mind is that, increasingly, official reports and evaluations, as well as academic studies, make use of complex indices of performance, which combine two or more elements (see for example Audit Commission, 2009; Pollitt, 2011; Van de Walle et al., 2008). These aggregated indices can be very useful to busy decision makers or to nonspecialists and citizens, but they may also (deliberately or inadvertently) conceal underlying trades-off between two or more desirable values (for instance equity versus efficiency). They can also give spurious precision to judgments which are more correctly seen as hedged about by quite wide brackets of uncertainty (Jacobs and Goddard, 2007).

When assessing effects there is also frequently a problem of attribution. That is to say, there may be evidence of, say, an increase in efficiency, but what exactly was the cause? If the creation of an agency structure was the only thing that happened during the relevant time period, then the efficiency gain might be plausibly attributed to that new structure. But if there were other developments at the same time (for example technological changes; a new management; a government-wide efficiency drive) then it can be very hard to assess what share of the efficiency gain (if any) should be attributed to agencification. This problem of multiple possible causes is actually very common in public management reform. And it tends 
to get worse the further one moves from changes in processes to changes in outputs to changes in outcomes.

\section{Methods and data}

The studies of the effects of the creation and operations of agencies reviewed in this article are derived from a database of 519 studies of NPM reforms across Europe. The database was created as part of an international comparative project involving ten research teams in nine European countries (Pollitt and Dan, 2011; Pollitt and Dan, 2013) ${ }^{1}$. The process of identifying and selecting the studies followed the following steps (see Pollitt and Dan, 2011, pp. 17-19 for further details):

a) Reviewed titles and keywords in articles published since 1980 (or later in case the first number of a journal appeared after 1980) in the following public administration and management journals: Journal of Public Administration Research and Theory, Public Administration, Governance, Public Administration Review, International Review of Administrative Sciences, International Public Management Journal, Public Management Review, Public Policy and Administration and Evaluation. The following keywords were used to guide the search: New Public Management (NPM), managerialism, performance, public sector reform, public management reform

b) Read the abstract of those articles that satisfied step a)

c) Submitted the articles that met step b) to a detailed review and made a decision for inclusion in the database on the basis of meeting cumulatively the following criteria:

- The study includes an evaluation of NPM reforms that have already been launched

- The NPM reforms have been partially or completely implemented and a formal ongoing or final evaluation has been conducted

- The study makes claims about the effects of NPM, and it provides evidence to support those claims.

Out of the total database, 72 studies refer to agencies in different countries across Europe (Table 1$)$. The majority of these studies $(74 \%)$ are academic, $10 \%$ consist of external and

\footnotetext{
${ }^{1}$ The database is available at http://www.cocops.eu/work-packages/wp1-npm-meta-analysis/database-ofstudies-of-npm-reforms-in-europe
} 
independent formal evaluations while the rest are internal evaluations or general official policy documents with elements of evaluation (Table 2). These numbers indicate that the proportion of practitioner studies is rather small $(10 \%)$ - the majority of the sample consists of independent academic work. A small fraction (7\%) comprises studies by various international organizations such as the World Bank or the OECD.

\section{Table 1. Countries covered}

\begin{tabular}{lll}
\hline Country & Number of studies & Percentage* $^{*}$ \\
\hline Austria (AT) & 6 & 8 \\
Belgium (BE) & 6 & 8 \\
France (FR) & 8 & 11 \\
Hungary (HU) & 2 & 3 \\
Italy (IT) & 6 & 8 \\
Latvia (LV) & 2 & 3 \\
Lithuania (LT) & 2 & 3 \\
Netherlands (NL) & 11 & 15 \\
Norway (NO) & 9 & 13 \\
Romania (RO) & 2 & 3 \\
Sweden (SE) & 2 & 3 \\
United Kingdom (UK) & 7 & 10 \\
Comparative studies & 12 & 17 \\
\hline
\end{tabular}

* Percentage of the total 72 studies of agencies.

Table 2. Type of studies

\begin{tabular}{lll}
\hline Type of study & Number of studies & Percentage* \\
\hline $\begin{array}{l}\text { Academic } \\
\text { General official policy reports with }\end{array}$ & 53 & 74 \\
$\quad$ some elements of evaluation & 3 & 4 \\
$\begin{array}{l}\text { Internal formal official evaluation } \\
\text { studies }\end{array}$ & 4 & 6 \\
$\begin{array}{l}\text { External and independent official } \\
\text { evaluation studies }\end{array}$ & 7 & 10 \\
Other & 5 & 7 \\
\hline Percentage of the total 72 studies of agencies.
\end{tabular}


A second step consisted of coding for each particular study the type of effects that were evaluated following the three-point typology introduced earlier: effects at the level of processes/activities, effects on outputs and effects on outcomes (see Table 3 below). The coding was implemented in Microsoft SharePoint which facilitated a count of each type of effect.

A third step consisted of selecting a number of studies of the total number of 72 studies of agencies and report for each of these studies the specific effects found. This includes the direction of change - whether the creation of agencies led to improvements, deteriorations or no "significant" change. The primary criterion for selecting the studies for the detailed analysis included the strength of method and evidence provided followed by geographic reach in an attempt to include studies in different European countries. A total of 28 studies across Europe resulted from this selection process (see Table 4 below). The selection enabled a more detailed analysis of those studies that provided more convincing evidence while at the same ensuring that the sample consists of evaluations of the effects of the creation of agencies in different national contexts. Of the 28 studies, only 3 are practitioner while the rest of 25 are academic.

\section{Findings}

A first main finding is that the literature on the effects of agencification in Europe has been much more concerned with evaluating changes in processes/activities than with changes in outputs and outcomes. Table 3 shows that $36 \%$ of the studies (26 studies) found evidence on outputs or outcomes and of these only $7 \%$ on outcomes. As a result, much more is known about the internal machinery of setting up and managing agencies than about the effects that agencies and their services have on service users and citizens. Compared to what the citizens 'get' as a result of agencification and how they are affected by it - outcomes - we know relatively more about what services agencies provide and how they provide them - outputs. This is reflected in Table 4 which shows specific examples of the effects of agencies. This is a first clear pattern to which the data point. 
Table 3. Studies of agencies by type of effects

\begin{tabular}{|c|c|c|}
\hline Subset & Number of studies & Percentage \\
\hline \multirow{2}{*}{$\begin{array}{l}\text { 1. All studies of agencies } \\
\text { 2. All studies including entries for } \\
\text { changes in activities/processes, } \\
\text { outputs or outcomes }\end{array}$} & 72 & 100 \\
\hline & 53 & 74 \\
\hline $\begin{array}{l}\text { 3. All studies including entries for } \\
\text { changes in outputs or outcomes }\end{array}$ & 26 & 36 \\
\hline $\begin{array}{l}\text { 4. All studies with entries for } \\
\text { changes in outcomes only }\end{array}$ & 5 & 7 \\
\hline
\end{tabular}




\begin{tabular}{|c|c|c|c|c|}
\hline Country & What was evaluated? & What were the expectations? & What were the effects? & Source \\
\hline \multirow[t]{2}{*}{ Austria } & $\begin{array}{l}\text { Evaluation of } \\
\text { Flexibilisierungsklausel, budget } \\
\text { execution within a framework of } \\
\text { performance agreements and targets. } \\
\text { Agencification more generally. } \\
\text { Federal administration level, various } \\
\text { policy areas }\end{array}$ & \multirow{2}{*}{$\begin{array}{l}\text { Increased managerial autonomy and use of } \\
\text { performance targets and agreements would } \\
\text { increase efficiency, effectiveness, } \\
\text { innovation and professionalism }\end{array}$} & $\begin{array}{l}\text { Improved efficiency resulting from input } \\
\text { reductions } \\
\text { Deteriorated organizational stability } \\
\text { Insufficient steering by parent ministries } \\
\text { Improved agency-level management } \\
\text { Increased savings (mostly staff } \\
\text { reductions) Increased customer service } \\
\text { Unchanged role of performance indicators } \\
\text { in steering }\end{array}$ & $\begin{array}{l}\text { Hammerschmid et al., } \\
\text { 2008; Hammerschmid et } \\
\text { al., 2012; Rossmann, 2001; } \\
\text { Rossmann and } \\
\text { Leitsmüller, 2010 }\end{array}$ \\
\hline & $\begin{array}{l}\text { Agencification more generally in } \\
\text { various policy areas }\end{array}$ & & $\begin{array}{l}\text { Reduced transparency (shadow budgets) } \\
\text { Reduced parliamentary control of } \\
\text { agencies } \\
\text { Unchanged or at most minor } \\
\text { improvements in efficiency and savings } \\
\text { Reduced steering by parent ministries and } \\
\text { internal control } \\
\text { Rising cost of top executives }\end{array}$ & Greiling, 2011 \\
\hline \multirow{3}{*}{ Belgium } & \multirow{3}{*}{$\begin{array}{l}\text { Innovative culture of state agencies } \\
\text { and factors influencing it. } \\
\text { Agencification more generally } \\
\text { affecting various policy areas }\end{array}$} & \multirow{3}{*}{$\begin{array}{l}\text { Greater autonomy of agencies and } \\
\text { increased control of results by parent } \\
\text { ministry would foster innovation, } \\
\text { specialization and expertize leading to } \\
\text { performance improvements }\end{array}$} & $\begin{array}{l}\text { Unchanged innovative activity and } \\
\text { behavior by state agencies. No significant } \\
\text { differences in results found between } \\
\text { Flanders and Norway }\end{array}$ & $\begin{array}{l}\text { Lægreid et al., } 2011 \\
\text { Comparative study } \\
\text { covering Flanders and } \\
\text { Norway }\end{array}$ \\
\hline & & & $\begin{array}{l}\text { Increased fragmentation in policy and } \\
\text { management. Coordination decreased in } \\
\text { all countries but to various degrees } \\
\text { depending on the intensity of } \\
\text { agencification (more in the Netherlands, } \\
\text { Sweden, the UK and New Zealand than in } \\
\text { Belgium and France) }\end{array}$ & $\begin{array}{l}\text { Bouckaert et al., } 2010 \\
\text { In addition to Belgium, it } \\
\text { includes France, } \\
\text { Netherlands, Sweden and } \\
\text { the UK }\end{array}$ \\
\hline & & & $\begin{array}{l}\text { Diminished transparency stemming from } \\
\text { high number of organizational forms } \\
\text { Decreased policy cohesion, } \\
\text { communication, collaboration and service }\end{array}$ & $\begin{array}{l}\text { Spanhove and Verhoest, } \\
2008 \\
\quad 10\end{array}$ \\
\hline
\end{tabular}




\begin{tabular}{|c|c|c|c|c|}
\hline & & & integration & \\
\hline & & & $\begin{array}{l}\text { Improved innovative activity and } \\
\text { behavior of state agencies }\end{array}$ & Verhoest et al., 2007 \\
\hline & $\begin{array}{l}\text { The performance of a Flemish } \\
\text { employment agency }\end{array}$ & $\begin{array}{l}\text { Managerial autonomy, results control, } \\
\text { financial incentives and competition would } \\
\text { lead to agency performance }\end{array}$ & $\begin{array}{l}\text { Improved effectiveness of the job } \\
\text { brokerage division but less so in the } \\
\text { vocational training division } \\
\text { Unchanged equal access - limited } \\
\text { representation of hard-to-place job } \\
\text { seekers }\end{array}$ & Verhoest, 2005 \\
\hline & $\begin{array}{l}\text { Evaluation of performance contracts } \\
\text { between six Flemish agencies and the } \\
\text { Flemish Government for } 2008 . \\
\text { Various policy areas. }\end{array}$ & $\begin{array}{l}\text { The introduction of performance contracts } \\
\text { would make the control relationship } \\
\text { between ministries and agencies more }\end{array}$ & $\begin{array}{l}\text { Limited use of performance contracts for } \\
\text { control } \\
\text { Problematic quality of performance } \\
\text { contracts, monitoring and evaluation } \\
\text { processes }\end{array}$ & Vlaams Parlement, 2009 \\
\hline & $\begin{array}{l}\text { Evaluation of performance contracts } \\
\text { for social security agencies }\end{array}$ & result-oriented & $\begin{array}{l}\text { Insufficient role played by the state in } \\
\text { negotiating performance contracts, setting } \\
\text { objectives and monitoring }\end{array}$ & Rekenhof, 2005 \\
\hline & Regional hospital agency of Brittany & Setting up flexible & $\begin{array}{l}\text { Tight central control of agencies, lack of } \\
\text { managerial flexibility of agencies in } \\
\text { negotiation } \\
\text { Improved overall cohesion and common } \\
\text { action }\end{array}$ & $\begin{array}{l}\text { Dumond and Jourdain, } \\
2006\end{array}$ \\
\hline France & $\begin{array}{l}\text { Creation of regional hospital agencies } \\
\text { more generally }\end{array}$ & $\begin{array}{l}\text { agencies would better respond to local } \\
\text { needs. They were designed to have a } \\
\text { regulatory role and were tasked to } \\
\text { restructure the health system }\end{array}$ & $\begin{array}{l}\text { Improved communication between } \\
\text { agencies and stakeholders leading to } \\
\text { improved accountability and transparency } \\
\text { Improved professionalization of the } \\
\text { management of regional agencies } \\
\text { Improved service coordination }\end{array}$ & Fargeon et al., 2002 \\
\hline & & & $\begin{array}{l}\text { Unclear effect on equal access to services } \\
\text { Unclear effects on cost containment and }\end{array}$ & Minvielle, 2006 \\
\hline
\end{tabular}




\begin{tabular}{|c|c|c|c|c|}
\hline & & & quality of service & \\
\hline Hungary & $\begin{array}{l}\text { Agencies under the ministry level in } \\
\text { various policy areas }\end{array}$ & $\begin{array}{l}\text { More complex than just the typical } \\
\text { expectations of public choice theorists. It } \\
\text { includes political reasons such as search for } \\
\text { legitimacy in the eyes of stakeholders }\end{array}$ & $\begin{array}{l}\text { Decreased organizational stability due to } \\
\text { specialization and fragmentation }\end{array}$ & György, 2010 \\
\hline Netherlands & $\begin{array}{l}\text { Agencification more generally. } \\
\text { Various policy areas }\end{array}$ & $\begin{array}{l}\text { Increase in managerial autonomy of } \\
\text { executive agencies would lead to greater } \\
\text { efficiency and responsiveness }\end{array}$ & $\begin{array}{l}\text { Improved managerial innovation } \\
\text { Improved result-oriented steering } \\
\text { Increased savings } \\
\text { Lowered organizational stability }\end{array}$ & $\begin{array}{l}\text { Kraak and van Oosteroom, } \\
2002\end{array}$ \\
\hline \multirow[t]{2}{*}{ Norway } & $\begin{array}{l}\text { Creation of a decentralized health } \\
\text { model where a high degree of } \\
\text { autonomy was granted to regional } \\
\text { and local health units, called health } \\
\text { enterprises }\end{array}$ & $\begin{array}{l}\text { The organization of hospitals as health } \\
\text { enterprises with decentralized, semi- } \\
\text { autonomous management would improve } \\
\text { efficiency and accountability through } \\
\text { greater access to information. They would } \\
\text { lead to lower bureaucracy and foster change }\end{array}$ & $\begin{array}{l}\text { Greater managerial and financial } \\
\text { autonomy of hospitals } \\
\text { Greater political control of health } \\
\text { enterprises }\end{array}$ & Lægreid et al., 2003 \\
\hline & $\begin{array}{l}\text { Creation of single purpose } \\
\text { organizations in various policy areas } \\
\text { more generally }\end{array}$ & $\begin{array}{l}\text { Reforms were driven less by economic } \\
\text { reasons than in other countries and more by } \\
\text { interest in becoming part of an international } \\
\text { reform trend of autonomization }\end{array}$ & $\begin{array}{l}\text { Coordination, capacity and fragmentation } \\
\text { problems } \\
\text { Undermined central political control and } \\
\text { weaker executive political leadership } \\
\text { compared to agency leadership }\end{array}$ & $\begin{array}{l}\text { Christensen, } 2001 \\
\text { Christensen and Lægreid, } \\
2009\end{array}$ \\
\hline Sweden & $\begin{array}{l}\text { Evaluation of the management by } \\
\text { results model with a focus on } \\
\text { agencification. Various policy areas }\end{array}$ & $\begin{array}{l}\text { Rational choice principles and expectations: } \\
\text { disaggregation to create savings, improved } \\
\text { efficiency and responsiveness. }\end{array}$ & $\begin{array}{l}\text { Enhanced understanding by ministries of } \\
\text { the activities of agencies } \\
\text { Improved awareness of agencies towards } \\
\text { results } \\
\text { Unclear and inadequate reporting } \\
\text { requirements developed by ministries } \\
\text { Poor link between inputs and outcomes }\end{array}$ & Sundström, 2007 \\
\hline \multirow[t]{2}{*}{ United Kingdom } & $\begin{array}{l}\text { More general review of effects of } \\
\text { agencification and NPM reforms in } \\
\text { various policy areas } \\
\text { In addition to the UK it includes } \\
\text { examples from Denmark, Germany, } \\
\text { Italy, Norway, Spain, Sweden, } \\
\text { Canada, USA and South Korea }\end{array}$ & $\begin{array}{l}\text { Overall, rational choice principles and } \\
\text { expectations: disaggregation to create } \\
\text { savings, improved efficiency and } \\
\text { responsiveness }\end{array}$ & $\begin{array}{l}\text { A statistical averaging of studies of the } \\
\text { effects of agencification on efficiency } \\
\text { finds efficiency 'up' in more cases than } \\
\text { 'down', but the largest category is } \\
\text { 'unchanged' }\end{array}$ & Andrews, 2010 \\
\hline & The creation of executive agencies in & The expectations were that greater & Improved accountability of agency chief & Office for Public Service \\
\hline
\end{tabular}




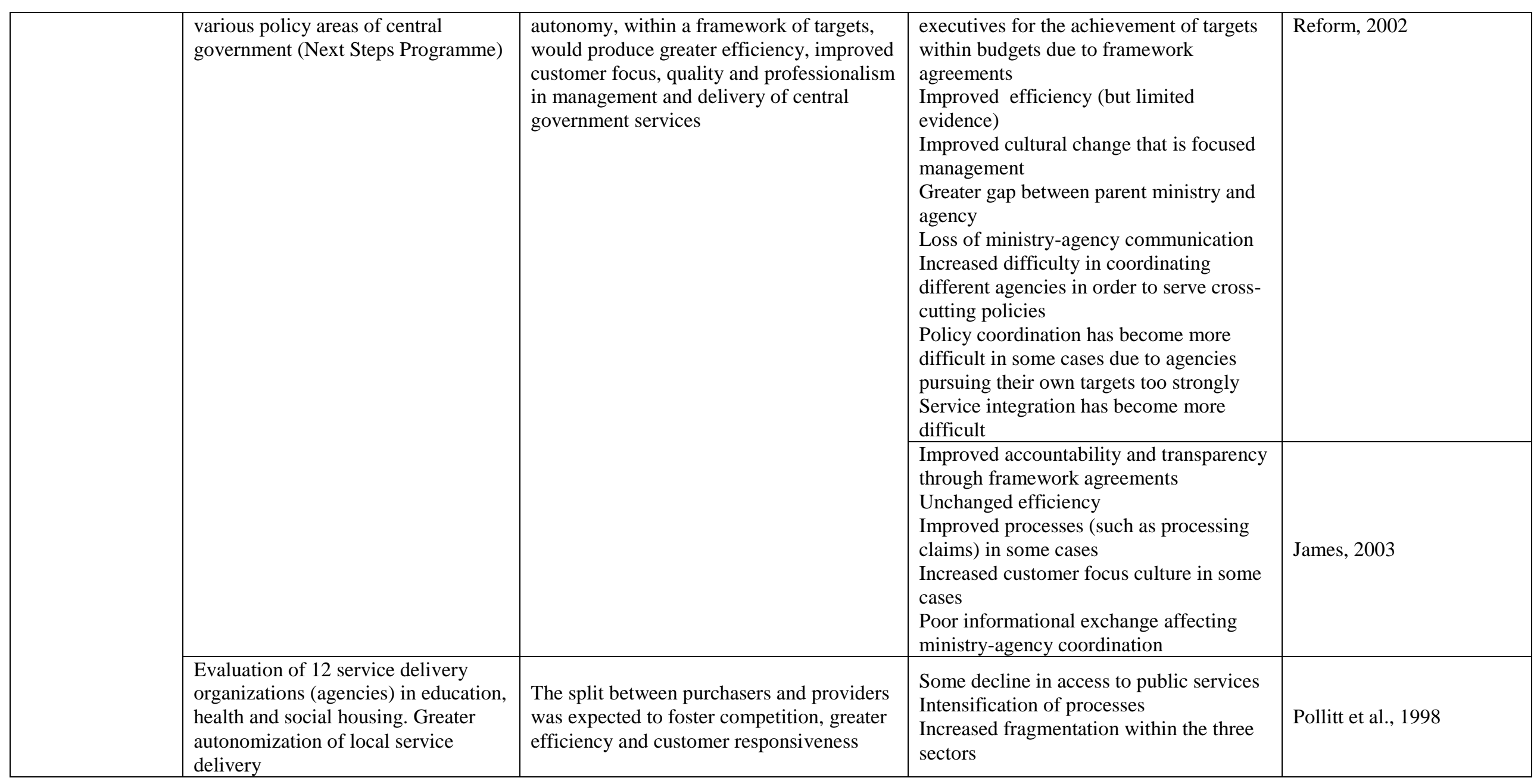




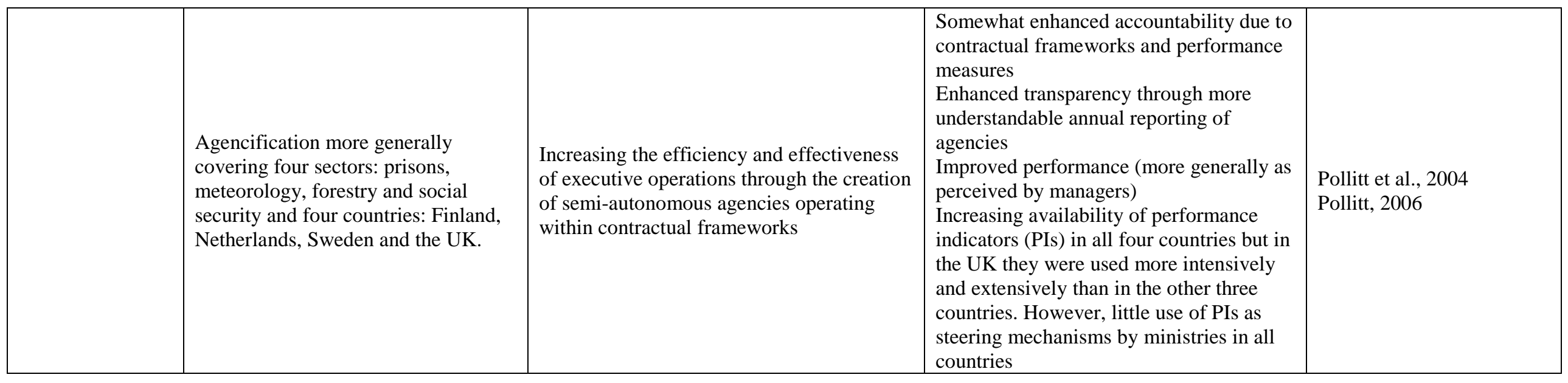

Table 4: Examples of effects of agency reform in Europe 
Although most of the convincing evidence only refers to changes in processes, a number of studies in our sample discuss effects of agencies on outputs and outcomes in various European countries, most notably in Austria, Belgium, France and the UK. Column "What were the effects? in Table 4 summarize these effects. A first notable example is the Austrian experience with agencification. External independent and academic evaluations - both of a decade ago and more recent - have found evidence on improved efficiency (Hammerschmid et al., 2008; Rossmann, 2001; Rossmann and Leitsmüller, 2010. These improvements are attributed to two main factors: i) improvements in management processes following an increase in autonomy and ii) a decrease in inputs consisting mostly of staff reductions. These findings are extremely interesting, but there is limited evidence of technical or X efficiency reflecting improvements in input-output ratios. With no or limited evidence on corresponding output levels, these efficiency improvements can best be described as savings or economies. Technical efficiency may have improved but there is simply not enough evidence to show that output levels improved, remained unchanged or decreased less than the level of inputs. However, overall, taking into account the evidence on processes, the Austria is among the most successful cases of the agency model - despite a number of unintended consequences as discussed in detail below. Another salient example refers to the creation of semi-autonomous regional hospital agencies in France. This was found to lead to improvements in transparency and accountability to various stakeholders including the public. The main factor explaining these positive effects is improved communication between agencies and stakeholders (Fargeon et al., 2002). However, no clear positive effects were found on cost containment, access to services or quality of healthcare (Minvielle, 2006). A case study evaluation concluded that the French regional healthcare agency model granted limited agency autonomy in the attempt to maintain central policy and service coordination and control. This decreased the negotiation power of regional agencies and managerial flexibility, but improved overall cohesion (Dumond and Jourdain, 2006). The UK studies of agencies evaluating the Next Steps Programme provide some evidence on changes in outputs and outcomes although the bulk of existing evidence refers to the processes of setting up and managing agencies. This includes improved accountability and transparency as a result of framework agreements and better reporting as well as changes in customer and result orientation and overall positive perceptions of performance (James, 2003; Pollitt et al., 2004; Pollitt, 2006). These findings 
point to certain improvements in outputs and outcomes in a number of countries, but the picture is far more nuanced with evidence of trade-offs and consequences in other areas that were not part of the original model - this is a pattern that is not exclusive to outputs and outcomes alone but is also common as we shall see to changes in processes or activities.

\section{Positive effects of agencification on processes/activities}

There is considerable evidence on various effects of the creation of agencies on processes/activities, as shown in Table 4. Compared to what we know about the outputs and outcomes of agencification, the evidence on processes is more convincing and more readily attributable to agencification. The data point to certain improvements in various countries in the management and organizational culture of government bodies following an increase in agency autonomy compared to agencies with tighter subordinate relations. These improvements have taken various forms, including an orientation towards the needs and demands of service users as evidenced in the case of Austrian, Dutch and UK agencies (Hammerschmid et al., 2008; James, 2003; Kraak and van Oosteroom, 2002; Pollitt et al., 2004; Pollitt, 2006; Rossmann, 2001). The management by results model promoted in Swedish agencies improved orientation towards results (Sundström, 2007). Similarly, improvements in the form of greater innovative activity were found in Flemish and Dutch agencies in various policy areas (Kraak and van Oosteroom, 2002; Verhoest et al., 2007). However, evidence in this particular area is mixed with another study finding no significant improvements in innovation in Belgium and Norway (Lægreid et al., 2011). These findings show that in some Western European countries (specifically Austria, Belgium, the Netherlands and the UK) the creation of agencies has intensified and improved management processes as a result of greater managerial flexibility, and some evidence exists of cultural change with a greater emphasis on identifying service users' needs and achieving results. This has not been the case, however, in those countries where agencies were granted limited autonomy. The French experimentation with setting up regional healthcare agencies is a case in point where tight central control left room for only limited managerial flexibility (Fargeon et al., 2002). The data seem to indicate that agency managers need to enjoy a high-enough degree of autonomy to 'give them space' to make decisions and incentivize them to think tactically and strategically to find ways to innovate and assume responsibility for performance. 
Despite this pattern of positive effects of agencification, the data show that the effects of agencification have been more complex and nuanced, and not uniformly positive. A number of unintended consequences - ignored by the more optimistic proponents of agencification are emphasized by the authors of the studies. This is a third pattern for which this review finds evidence.

\section{Unintended consequences: mixed and nuanced effects of agencification}

The main unintended consequences, identified by 13 studies (46\% of the sample), consist of lowered organizational stability, diminished central coordination and increased fragmentation. Issues of national coordination in a context of agencification have been found in Austria (for example Greiling, 2011; Hammerschmid et al., 2008; Rossmann and Leitsmüller, 2010), Belgium (Bouckaert et al., 2010; Spanhove and Verhoest, 2008), Hungary (György, 2010), the Netherlands (Kraak and van Oosteroom, 2002), Norway (for example Christensen and Lægreid, 2009) and the UK (James, 2003; Pollitt et al., 2004). Agency autonomy - depending on its degree - has created organizational incentives to improve performance, but it has raised challenges to coordination and performance of the whole system. Although agencification has not 'invented' the need for systemic coordination, processes of autonomization have reinforced it. The sample, however, points to limited empirical evidence documenting the effects of coordination problems. It readily describes the need for coordination following fragmentation in the public sector as a result of agency proliferation, but efforts to improve coordination need to be based on evidence on what negative effects these coordination problems have reinforced. This is an area where further research is needed especially in the current context where 'joining-up' policies are promoted in various European countries.

A second unintended consequence concerns transparency and accountability. Seven studies in the sample (25\%) have found evidence of either a decrease or - interestingly - an increase in accountability and/or transparency. For example in Austria, Greiling (2011) found that agency activity and leadership became less transparent due to the use of shadow budgets coupled with rising costs of top executives. Increased fragmentation, due to a large number of organizational forms in the agency landscape in Flanders, diminished transparency (Spanhove and Verhoest, 2008). In other countries, however, performance management and agencification enhanced accountability and transparency depending on the clarity and 
comprehensiveness of reporting guidelines, frameworks and performance measures developed by ministries (for example Sundström, 2007 in the case of Sweden or see Pollitt et al., 2004 and Pollitt, 2006 for evidence in various sectors in Finland, the Netherlands, Sweden and the UK). We see how these factors affect the 'success' of agencification in improving accountability and transparency. Reporting requirements of ministries on agency activity and performance need to be clear and understandable to improve agency-ministry communication. Poor information exchange, by contrast, can reinforce agencies to look "inwards" and pursue their own targets leading to a loss in central steering and coordination.

\section{Conclusions}

Agencification has been seen as a route to economies (input minimization) to more professional management (better processes), to greater efficiency (an improved input/output ratio), and to higher customer responsiveness and service quality (better outcomes). The evidence, however, becomes thinner the further one moves towards outcomes - we know much more about how the creation of agencies affected the internal relations within ministries than we do about how they actually changed service quality. A count of the type of effects evaluated in the sample indicates that relatively little is known about outcomes: that is effects outside the administrative system and the so-called 'democratic effects' - effects on legitimacy and accountability towards society (Van Thiel et al., 2012, pp. 432-435). Of the sample reviewed in this study, $36 \%$ includes some type of evidence on outputs, efficiency or outcomes. However, only $7 \%$ of these discuss outcomes.

The empirical research across Western Europe reviewed here found evidence of improvements in the organization and management processes of agencies following an increase in managerial autonomy. Likewise, evidence exists of cultural change with greater interest and emphasis on achieving results and focusing on service users' needs and demands. These two types of evidence seem consistent across policy areas and countries, and is one main pattern to which this review points. They show that agencification can and has led to or reinforced certain positive effects in the organization, management and delivery of public services. The issue is that little is known about what outcomes these positive developments have led to and whether they have much - or anything to do - with the creation, autonomy and management of agencies. 
A second main pattern identified shows that the creation of agencies across European public sectors has led to nuanced and mixed effects with improvements in some areas, but also to insignificant changes or even deteriorations in other areas. A total of $46 \%$ of the sample found evidence of problems with organizational stability, fragmentation or coordination in a context of agencification. While this pattern is common across different European countries, these challenges varied depending on the intensity of agencification and the effectiveness of coordination mechanisms and instruments put in place to address fragmentation and coordination problems. This type of problems has by far been the most frequent identified in the reviewed sample. A second unintended consequence refers to concerns with accountability and transparency, but evidence is mixed with only two studies finding deteriorations in Austria and Belgium while six studies found evidence of improved accountability and transparency particularly in Sweden and the UK. Key factors that can facilitate the accountability and transparency of agencies lies in improved communication with stakeholders, both political and the public, clear and comprehensive exchange of information, guidelines and reporting requirements coupled with understandable contractual frameworks and performance measures.

This paper has looked at the effects of agencification, and reviewed a sample of studies of agencies derived from the NPM literature. There are good reasons to do this. Agencification in a context of performance frameworks has been a key pillar of the NPM, and has spawned great interest for academics and practitioners alike. This is reflected in the number of studies of agencies - both single-country and comparative - that have been conducted in the past two decades. It needs to be acknowledged, however, that agencies have been created for other reasons and strands of literature other than NPM may well include evidence on the impacts of agencies. The goal here was to look at the NPM literature on agencies, and the sample reviewed here is based on a large database of studies of NPM, which systematically collected studies of NPM since the early 1980s across Europe. In this sense, it can be argued first that the net was cast wide enough by including in the sample a variety of studies across Europe. Second, by carefully reviewing 28 studies selected based on the strength of method and evidence provided, the article sought to identify nuances and possible patterns based on empirical literature that provided more convincing evidence of effects.

The priority for future research into agencies should be the direct study of changes in outputs and, especially, outcomes. For the public these are the real 'results' of reform, but they have 
been far less often studied than changes in organizational structures and processes. That, of course, is partly because they are more difficult to study practically and politically. Once created, agencies have undergone change in their organization and management as well as in the agency landscape. This has taken place in a context of cost cutting and achieving savings in the public sector which translated into reductions in the number of agencies, recentralization, and central steering and coordination efforts. A relevant second line of research into agencies is to document whether these changes to the 'autonomizing' agency model proved effective. Compared to the previous state of affairs, did they bring about the anticipated savings, improvements in quality and access to services? Did they improve outcomes or has there been a drop in outcomes, and if so, can they be convincingly attributed to changes in the original agency model? These questions form a second line of needed research into agencies.

In conclusion, the picture of the effects of agencification is more nuanced than the proponents of agencification had originally envisaged. Unintended consequences received little consideration in the models that saw agencification as a panacea for various public sector ills. In this sense the evidence reviewed here challenges the original model of agencification proposed years ago by enthusiastic public choice theorists in the Anglophone world. In the current context of fiscal stringency with a growing interest in 'joining-up' initiatives and reductions in the number of agencies in various European countries, the 'autonomizing' model - the more disaggregation and the greater autonomy, the better - has already come under fire. This seems fair, but the challenge is not to transform, let us call it, 'deagencification' in another yet know-it-all model. There are inherent trade-offs, paradoxes and unintended consequences, some of which are clear in this article, between granting organizational-level autonomy and centrally consolidating control. It can be expected that stronger central coordination at the expense of organizational autonomy may lead to disincentives to innovate and overall assume responsibility for decisions and results. There may well be a price that needs to be paid. The question, however, is whether reforms of the agency model aimed at greater central control, coordination or steering at the expense of agency discretion, bring about savings and greater 'systemic' performance in the public sector compared to a disaggregated and autonomous agency model. 


\section{Acknowledgements}

I would like to acknowledge the contribution of Christopher Pollitt, who reviewed a previous draft and is the co-author of previous joint work on which this paper is based. This article is based on a report prepared for the Dutch Senate into the effects of agencification and privatization on the relationship between citizens and the national government led by Sandra Van Thiel, who supported further research in this area.

\section{Funding acknowledgement}

The research leading to these results has received funding from the European Union's Seventh Framework Programme under grant agreement No. 266887 (Project COCOPS), Socio-economic Sciences \& Humanities. 


\section{References}

Andrews R (2010) New public management and the search for efficiency. In:

Christensen T and Lægreid P (eds) The Ashgate research companion to new public management. Aldershot: Ashgate, pp. 281-294.

Audit Commission (2009) Final score: the impact of Comprehensive Performance Assessment of local government, 2002-2008. London, The Audit Commission.

Boyne GA, Farrell C, Law J, Powell M and Walker RM (2003) Evaluating Public Management Reforms. Buckingham: Open University Press.

Bouckaert G, Peters BG and Verhoest K (2010) The coordination of public sector organizations, shifting patterns of public management. Basingstoke: Palgrave MacMillan.

Buchanan A (1988) Principle/agent theory and decision making in healthcare. Bioethics 2(4): 317-333.

Christensen T (2001) Administrative reform: changing leadership roles. Governance 14 (4): 457-480.

Christensen T and Lægreid P (2009) Public management reform in Norway: reluctance and tensions. In: Goldfinch SF and Wallis JL (eds) International Handbook of Public Management Reform, Cheltenham: Edward Elgar, pp. 300-316.

Downs A (1967) Inside bureaucracy. Boston: Little, Brown.

Dumond JP, Jourdain A (2006) L'action publique entre la planification et la contractualisation négociée: la perception des administrateurs des hôpitaux. Politiques et Management Public 24(2): 1-19.

Fargeon V, Minvielle E, Valette A and Denis JL (2002) Les agences régionales de l'hospitalisation ont cinq ans: bouleversement ou aménagement d'un dispositif de régulation? Politiques et management public 20(2) juin.

Kettl DF (1997) The Global Revolution in Public Management: Driving Themes, Missing Links. Journal of Policy Analysis and Management 16(3): 446-462.

Greiling D (2011) Ausgliederungen und Public Private Partnerships als Instrumente zur Erfüllung öffentlicher Aufgaben: ein österreichischer Erfahrungsbericht. In: ZögU. Nr. 1/2011. S. 52-80.

Hajnal G (2010) Agencies in Hungary: uses and misuses of a concept. In: Lægreid P and Verhoest K (eds) Governance of public sector organizations: autonomy, control and performance, Houndmills and New YorK: Palgrave Macmillan, pp. 44-65.

Hammerschmid G, Egger-Peitler I and Höllerer M (2008) Evaluierung des Instruments der Flexibilisierungsklausel, Endbericht, Wien.

Hammerschmid G, Krischok A and Steigenberger K (2012) Agencification experiences in Austria. In: Verhoest K, Van Thiel S, Bouckaert G and Lægreid P (eds) Government Agencies: Practices and Lessons from 30 Countries, Basingstoke: Palgrave Macmillan, pp. 156-165.

James O (2003) The executive agency revolution in Whitehall: public interest versus bureau shaping perspectives. Basingstoke: Palgrave Macmillan. 
Jacobs R and Goddard M (2007) How do performance indicators add up? An examination of composite indicators in public services. Public Money \& Management 27(2): 103-110.

Jensen MJ and Meckling MJ (1976) Theory of the firm: managerial behavior, agency costs and ownership structure. Journal of Financial Economics 3: 305-360.

Kraak A and Van Oosteroom R (2002) Agentschappen: innovatie in bedrijfsvoering. Een resultaatgericht besturingsmodel bij uitvoeringsorganisaties van de rijksoverheid.

Lægreid P, Opedal S and Stigen I (2003) The Norwegian hospital reform: balancing political and enterprose autonomy. Working paper 23, Bergen, Stein Rokkan Centre for Social Studies.

Lægreid P, Roness P and Verhoest K (2011) Explaining innovative culture and behaviour of state agencies. Organizational Studies 32(8): 1-27.

Manning N and Matsuda Y (2000) Difficulties with Autonomous Agencies. Available at: http://web.archive.org/web/20051113030116/http://www1.worldbank.org/publicsector/civ ilservice/autonomous.htm (accessed 6 May 2013).

Minvielle E (2006) New public management à la française: The case of regional hospital agencies. Public Administration Review, September/October.

Niskanen WA (1968) The peculiar economics of bureaucracy. American Economic Review 58: 293-305.

Niskanen WA (1971) Bureaucracy and representative government. Chicago: AldineAtherton.

Office of Public Services Reform (2002) Better government services: executive agencies in the $21^{\text {st }}$ century, London, Cabinet Office.

Pollitt C (1993) Managerialism and the public services. Second edition. Blackwell: Oxford.

Pollitt C (2006) Performance management in practice: a comparative study of executive agencies. Journal of Public Administration Research and Theory 16(1): 25-44.

Pollitt C (2009) Structural change and public service performance. Public Money and Management 29(5): 285-291.

Pollitt C (2011) Moderation in all things: international comparisons of governance quality. Financial Accountability and Management 27(4): 437-457.

Pollitt C, Birchall J and Putman K (1998) Decentralising public service management. Basingstoke: MacMillan.

Pollitt C, Talbot C, Caulfield J and Smullen A. (2004) Agencies: how governments do things through semi-autonomous organizations. Basingstoke: Macmillan.

Pollitt C and Talbot C (2004) Unbundled government: a critical analysis of the global trend to agencies, quangos and contractualisation (eds) London and New York: Routledge/Taylor and Francis.

Pollitt C and Bouckaert G (2011) Public management reform: a comparative analysis: New Public management, governance, and the Neo-Weberian State. Oxford: Oxford University Press.

Pollitt C and Dan S (2011) The impacts of the New Public Management in Europe: A meta-analysis. Report. COCOPS project. 
Pollitt C and Dan S (2013) Searching for impacts in performance-oriented management reform: A review of the European literature. Public Performance \& Management Review 37(1):7-32.

Preker AS and Harding A (2003) Innovations in health service delivery: the corporatization of public hospitals (eds) Washington, DC: World Bank.

Rekenhof (2005) De bestuursovereenkomsten van de openbare instellingen van sociale zekerheid. Een beheersinstrument voor de Staat, Verslag van het Rekenhof aan de Kamer van Volksvertegenwoordigers, Brussel.

Rossmann B (2001) Ausgliederungen: Kein Ersatz für eine Reform des öffentlichen Sektors. Wiso 3/2001. Linz 2001, pp. 139-157.

Rossmann B and Leitsmüller H (2010) Ausgliederungen aus den öffentlichen Haushalten Versuch eines Resümees. In Schlager C. (Ed.) Ausgliederungen aus dem öffentlichen Bereich-Versuch einer Bilanz, Wien, Wirtschaftswissenschaftliche Tagungen der AK Wien, Band 15.

Smullen A (2010) Translating agency reforms: rhetoric and culture in comparative Perspective. Basingstoke: Palgrave Macmillan.

Spanhove J and Verhoest K (2008) Deugdelijk Bestuur in de Vlaamse Overheid anno 2008: een kwalitatieve analyse van nieuwe Government Governance mechanismen in BBB, 180 pp. Leuven: SBOV.

Sundström G (2006) Management by results: its origins and development in the case of the Swedish state. International Public Management Journal 9(4): 399-427.

Tsoukas H (2005) Complex knowledge: studies in organizational epistemology. Oxford: Oxford University Press.

Van de Walle S, Van Roosbroek S and Bouckaert G (2008) Trust in the public sector: is there any evidence for a long term decline? International Review of Administrative Sciences 74(1): 47-64.

Van Thiel S (2001) Quangos: trends, causes and consequences. Aldershot: Ashgate

Van Thiel S (2012) Comparing agencies across countries. In: Verhoest K, Van Thiel S, Bouckaert G and Lægreid P (eds) Government Agencies:

Practices and Lessons from 30 Countries, Basingstoke: Palgrave Macmillan, pp. 18-26.

Van Thiel S and Pollitt C (2007) The management and control of executive agencies: an Anglo-Dutch comparison. In: Pollitt C, Van Thiel S and Homburg, V (eds) New Public Management in Europe: adaptation and alternatives, Basingstoke: Palgrave Macmillan, pp. 52-70.

Verhoest K (2005) Effects of autonomy, performance, contracting and competition on the performance of a public agency: a case study. Policy Studies Journal 33(2): 235-258.

Verhoest K, Verschuere B and Bouckaert G. (2007) Pressure, legitimacy and innovative behaviour by public organizations. Governance 20(3): 469-496.

Verhoest K, Van Thiel S, Bouckaert G and Lægreid P (2012) Government Agencies: Practices and Lessons from 30 Countries (eds) Basingstoke: Palgrave Macmillan.

Vlaams Parlement (2009) Stuk 37-I (2009-2010), Nr. 1, Brussel. 